\title{
Examination of Preschool Teachers' Opinion on Alternative Assessment ${ }^{\mathrm{i}}$
}

\author{
İsa Kaya \\ Education of Faculty, Fatih Sultan Mehmet Vakıf University, İstanbul, Turkey
}

Copyright $(2018$ by authors, all rights reserved. Authors agree that this article remains permanently open access under the terms of the Creative Commons Attribution License 4.0 International License

\begin{abstract}
This research intended to determine the alternative assessment methods used by the preschool teachers and their opinions, knowledge and competencies related to these methods. The research group of the study comprised of 10 kindergarten teachers working in Konya province during the 2017-2018 academic year in Turkey. The data obtained through the semi-structured interview form were evaluated by descriptive analysis. As a result of the research, it has been understood that preschool teachers have benefited from play-based assessment in order to gain concrete information in recognizing and evaluating the children through play. In the portfolio assessments, they have different opinions and applications in using the information and activities in the portfolio. In the program-based assessment, teachers assess children within the framework of training plans through a variety of forms, but teachers claimed that it is not effective to use the program-based approach to assess the aims and achievements of the program and the development of students. Moreover, it has been stated that the dynamic assessment approach is a new and unknown approach to the teachers, and the applications on this approach are limited. Teachers have found themselves unsatisfied in implementing alternative assessment approaches, but it has been understood that teachers are willing to develop themselves.
\end{abstract}

Keywords Preschool Education, Alternative Assessment, Portfolio, Program Based Assessment, Play Based Assessment, Dynamic Assessment

\section{Introduction}

It is important to assess the development of the child during preschool education period because considering the speed of early childhood development and the contribution of learning experiences to the later years require appropriate assessments to eliminate possible risk factors in the lives of children [1]. Regular and continuous collection of data on children's learning and development is necessary in order to make correct decisions about teaching. Bredekamp [2] defined assessment as the process of regular data collection as well as organizing and interpreting the information related to children's learning and development in order to make the right decisions about teaching. The Assessment is based on estimating information about a subject or a student by interpreting the collected information from various sources according to certain criteria. As the assessment is an integral step in learning and teacher activities, all sorts of tools and techniques are used to collect information about student behaviors [3].

Because of the pace of development, family structure, social and environmental experiences that underlie the individual differences in development, alternative searches have been made to evaluate children [4]. With the influence of the constructivist approach, the traditional assessment and evaluation of the results have been replaced by alternative assessments depending on the process. Alternative assessment is also expressed in the literature with the concepts of authentic assessment and portfolio assessment [5-7]. In this context, alternative measurement assessment tools include student-centered approaches that assess the process as well as the product. These tools contribute to the evaluation of learning beyond grading while informing students about the progress and deficiencies [5]. Erdoğan and Canbeldek [8], Gullo [6], Bracken [9] and Lidz [10] have identified alternative assessment approaches that can be used by the pre-school teachers in the educational process as play-based assessment, dynamic assessment, program-based evaluation and portfolio assessment.

Play is an important opportunity in the development and education of the child. The value of play in the development and evaluation of the child is significant because it opens the doors to communicate, identify self, and reflect emotions universally [11]. Play is a widely used evaluation approach in pre-school education because it allows observation, recognition and evaluation without breaking the child from the natural environment. 
Play-based assessment is the most widely used assessment approach in preschool education. Bracken [9] defined play-based assessment as the process by which children's all areas of development can be observed in a structured or unstructured play context. The teacher collects information about the child by means of systematic observation form, play observation form, anecdote recording form, achievement \& evaluation form, development checklist in the play. Observation records are analyzed by teachers to detect children's capabilities as dependent on and independent from the support of individuals around a child. Then, teachers aim to develop learning activities to address the needs of children. Through the play, there is evaluation and assessment of children's attitudes and capabilities. Moreover, in a play based evaluation, systematically developed scales such as "TPBA" and "PIECES" can be used [8].

Dynamic assessment is the process by which the individual learns his/her talents together with his/her learning potential [12]. Dynamic assessment is an alternative form of assessment that can be combined with other forms of assessment. In this assessment, the student participates in the learning process through direct learning experiences. This approach uses test retest design. A mediating learning experience can be described as an interaction between an evaluator and a child. Thus, the approach combines both assessment and teaching. The dynamic assessment is based on the theoretical work of Vygotsky [6]. Dynamic assessment has two stages. In the first stage, the child builds up in a close-knit development area and can perform his or her task in a subject that the child has not specialized in. If the child completes this task without support, a more difficult task is directed at the child. The second stage is completed with the support of an adult. At this stage, the child is provided with the support needed to reach the first stage [13].

Education systems become functional with educational programs. Educational programs are defined as all activities carried out by individuals towards the aims of the Ministry of National Education. Programs implemented in educational institutions are revised and developed with renewal and reorganization. This development and renewal includes a comprehensive program-based assessment [14]. Program-based assessment focuses on the content of the curriculum used in preschool education and on instructional strategies [6]. Before making any program-based assessments, the teacher should ask what the purpose of the assessment is. This question sets out important points about how to evaluate the answers. Program-based assessment in pre-primary education contributes to improvement of education and training, identification of children with special learning or developmental needs, assessment of program goals and achievements, and assessment of student development [2]. For this purpose, the program's deficiencies are reviewed, and the program becomes more effective [8].
Portfolio is also one of the most widely used assessment approaches in preschool education. F. L. Paulson, P. R. Paulson, and Meyer [15] identified portfolio assessment as a sum of student studies reflecting the successes of the learners' efforts. The portfolio is a system suitable for giving organized information about children. The collection and observation records of the child's work reflect the child's progress over time. There is no particular type of portfolio; thus, the content and design of it should be made based on the aim of the portfolio. The content of the portfolio includes both work samples and observation records [16]. Examples of work include the student's current work, photographs of children's work, videos and audio recordings. Portfolios not only contain the children's working examples or combinations of working examples, but also include observational records. A good teacher knows how much children gained development, and what precautions can be taken in unexpected cases [17].

In Turkey, teachers' perceptions and usage of alternative assessment methods have been investigated in branches outside the pre-primary education field. Teachers' attitudes tend to have a tendency to use the portfolio by comparing alternative assessment methods with traditional measurement techniques [18-21]. The majority of the researches related to assessment in preschool education are directed at the general assessment and portfolio [22, 23]. No research has been found in the literature to determine preschool teachers' views on alternative assessment approaches.

The purpose of this research was to establish the opinions of preschool teachers regarding the implementation of alternative assessment. The basic problem of research; what are the teachers' perceptions of alternative assessment in preschool settings?

For this purpose, answers to the following sub-questions were sought.

1. What are the teachers' views on portfolio assessment practices?

2. What are the opinions of the teachers on the implementation of the dynamic assessment?

3. What are the views of teachers on the implementation of play-based assessments?

4. What are the opinions of the teachers on the implementation of the program-based assessment?

5. What are the opinions of the teachers on their self-sufficiency in alternative assessment?

\section{Materials and Methods}

\subsection{Research Method}

It is a descriptive research, and the data are gathered by interview method from qualitative research methods. By descriptive research, researchers summarize the characteristics, talents, preferences and behaviors of 
individuals [24]. Interviewing is the most appropriate way to learn about the reasons for one's behavior and the opinions or feelings of another because one can freely express his/her feelings, thoughts and opinions within the context of answers to open-ended questions [25]. This study also tried to describe the views of preschool teachers about using alternative assessment approaches.

\subsection{Research Sample}

The study group was identified by purposeful sampling. Purposeful sampling means observing the most appropriate part of the universe. Depending on the objective of the study, it is possible to perform a deep research by selecting situations that are rich in terms of information. Depending on the objective of the study, teachers who participated in the study were selected among teachers who work in primary schools and kindergartens affiliated to Ministry of Education in Turkey, have been working for minimum five years, have completed undergraduate education and have accepted to perform interview. 8 of the teachers who participated in the study are women and 2 are men, and 8 of the teachers work in kindergarten and 2 work in the primary school.

\subsection{Data Collection and Analysis}

The data were obtained by a semi-structured opinion form developed by the researcher. The interview form was examined by two specialist academicians and at the same time, clarity and data were evaluated in terms of competence in the aggregate. The interviews took place in a silent environment outside the school and continued for around $10-12$ minutes. Before the start of the interview, the researcher obtained the permission of the participants on the objective of the interview, how and where the data will be used and recording of the interview by voice recorder. Meanwhile, the points which were emphasized by the participant during the interview and which were considered to be important were recorded in the interview form by the researcher. In order to conduct a descriptive analysis, the voice records were transcribed as data. In descriptive analysis, the data were first described in a logical and understandable way and then these descriptions were interpreted. A number of conclusions were reached by examining the causal associations. The aim of this kind of analysis was to present the findings in an organized and interpreted way [26].

\section{Findings}

In order to reveal the opinions of preschool teachers about alternative assessment approaches, "applications based on play-based assessment" was first sought via semi-structured interview form. The teachers view play as an important method of recognizing and evaluating the child. Some teachers keep brief notes about children in children's plays and others evaluate children by recording observations about children in observation forms.

"I usually watch children during free play time, I write on an observation form so that I do not forget my observations, then I use these observations when writing a progress report"T4.

The teachers stated that they observed and evaluated the children in their learning centers, and that these centers directed the children to recognize the child, and that they also actively participated in the plays of the children.

"Children love to play in various play centers, these centers provide excellent data for recognition and assessment, usually, boys play in the block center, girls prefer the dramatic play center" T8. The teachers stated that they can evaluate the basic characteristics of children, leadership qualities, sociability and social development in the play-based assessment.

"Through plays, I observe the children. Some kids always want to be the leaders in plays. In preschool education, we make lots of assessments about the social characteristics of children during plays" T3. It is understood that the answers given by the preschool teachers to the questions about the dynamic assessment process are that the teachers do not have knowledge about this assessment process, and they cannot apply this approach in the education process systematically. The teachers, however, have indicated that in some activities they perform similar activities to the dynamic assessment studies in a systematic way with their individual activities and assessment studies on children.

".......... .. for the first time I heard about this assessment. We usually keep a portfolio. ...we evaluate the levels of children over time. We do not evaluate the areas in which children develop "T5.

The teachers have expressed that they assess children in their existing developmental situation in terms of their ability to perform tasks independently, but do not assess and plan to support the developmental areas of the child.

"......for example; we support a child if he keeps the scissors straight and cuts the circle. We usually evaluate that children getting support are not capable of cutting. Anyway, we still give the support that the child needs. I did not make an assessment of how much the child could do by giving a more difficult task "T2.

The studies on portfolio assessment applications seem to be closely related to all of the teachers, but there are different applications for evaluating the contents of files according to certain criteria. Some of the teachers stated that they put all the forms and information about the students and their families in the portfolio file and they also put some activities which are part of the child's assessment of his/her development.

"I think the portfolio is important in preschool education. I put in activities through which I get information about children. They have information about the family history of 
the child. I keep similar activities and painting activities in the activity file daily" $\mathrm{T} 6$.

Some teachers, who said that they evaluate the development of children by reviewing the activities of the student portfolio periodically, expressed that they share this data by organizing meetings from time to time.

"Not all the time; but, I try to interview each parent once a year. I share the notes I keep during the year, the short notes I keep about the activities that I put out by ditching the child's portfolio file, the assessment I made myself by considering the child's developmental characteristics" T10.

Some teachers have indicated that they are obligated to keep the Portfolio, and that this does not provide them with any benefits excluding regular basis of children's activities. During the term, because of the high number of children, activities and limited knowledge about the assessment of activities, teachers claim that they do not benefit from the portfolio efficiently.

"...I send this file to the home the end of the term. There are too many activity files. There is no place to place them at school " T7.

The teachers stated that they assessed effectiveness in the activity plan with the program-based assessment, assessed the day in the daily flow plan, and evaluated the activities, concepts and adaptation studies that they took into the plan in the month on the monthly plan. While some teachers indicated that they make use of this assessment during the effective planning process, some also stated that they could not use these assessments for a variety of reasons.

"....... I regularly evaluate my plans, in terms of the program, the child's point of view. Then, I look at these writings when I make a new plan in the following years. I do not plan on activities which are beyond the children's capabilities and attention "T1.

The teachers indicated that they could follow regularly what outcomes / indicators and concepts they included in the program with the schedule of giving and showing for their monthly plans, but did not use any forms to follow the outcomes/ indicators and concepts of the children in the class. The teachers also stated that they evaluated the behaviors, achievements and concepts indicated in the program by observing the children's development levels.

"The forms that include the benefits and concepts in the program make our work easier, but sometimes I think. I have included all the achievements in my plan. But did the child gain them? There is no form to observe whether the child as gained them. I do not keep record of it because it is not compulsory. Now, I look at the whole class. For example; If more than half of the class is washing their hand, I count the children who grasped the hand wash" T5.

Teachers who have taken a long time in program-based assessment studies have indicated that they use these assessment studies in the improvement of the program, in the revision of the plans, in the updating of the achievements in their plans.
"There are many parts of assessment, my class is too crowded to find time and sometimes I do not feel adequate to evaluate them. In fact, you need to do it regularly "T3.

Most of the teachers expressed that, from among the alternative assessment applications, they considered themselves sufficient in the portfolio assessment, program based and play based assessment and they did not consider themselves sufficient in dynamic assessment and that they needed support.

"...I do not consider myself sufficient in dynamic assessment, I will go to a seminar on this issue if there is one" $\mathrm{T} 4$.

"...I consider myself sufficient in portfolio assessment among these. I need support in others" T10.

"...I have lack of information related to dynamic assessment and I consider myself sufficient in this issue. I apply other alternative assessment methods in the education process and I consider myself sufficient"T5.

\section{Discussion and Conclusions}

In this study, it was aimed to determine the opinions of preschool teachers regarding alternative assessment approaches. A descriptive analysis of the data obtained with the semi-structured interview form was made.

According to the findings, preschool teachers frequently used play-based assessment from alternative assessment approaches, and they also stated that they have acquired concrete information through recognition and assessment of children through play. While evaluating the portfolio, the teachers maintained a portfolio file but found that they had different opinions and practices in using the information and activities in the file as an assessment tool. It has been understood that teachers have carried out their assessment studies with a program-based approach within the framework of training plans and have made assessments about the program through various forms. However, it has been observed that the program's objectives / outcomes did not effectively use the program-based approach to assess the development of students. It is understood from the expressions of the teachers that they first heard the dynamic assessment approach and the practices of this approach were limited. The majority of preschool teachers do not consider themselves adequately trained to apply alternative assessment approaches; they want to improve themselves.

In the study conducted by 4th and 5th grade teachers in Kuran and Kanatli [20] teachers found that they had problems using alternative assessment approaches because of limited time, lack of resources, crowded classrooms, lack of interest of students and parents, and lack of knowledge about alternative assessments. Similarly, Çoruhlu et al. [27] found that teachers began to apply the program without having sufficient knowledge and skills on alternative assessment approaches, and that they did not 
have the knowledge and skills to create and evaluate a portfolio file in their research on semi-structured interview questions.

Karamustafaoğlu et al. [5] examined the level of knowledge about alternative assessments by classroom teachers, while some of the teachers are well-informed and self-sufficient, others do not see themselves as adequately trained. In the same study, it was revealed that the class teachers lacked information about alternative assessment techniques. In their research with 34 preschool teachers, Topuz and Kaya [22] found that they usually made assessments at the learning centers during play. Because of the crowdedness of the classes, teachers claimed that they have limited assessment opportunities and strategies.

The research of Sezer [28] on teachers' use of portfolios found that the majority of preschool teachers are implementing assessment tools. However, they have found that teachers are ambivalent about the adequacy of these instruments, that they find the validity and reliability of some tools and methods to be low, and that some tools and methods are not objective.

According to Özkan [29]'s research, the portfolio and development report were used as a recording and information sharing between all teachers. The teachers were forced to keep records of assessments, and the causes of difficulties were shown as the occurrence of instantaneous situations in the class due to the crowdedness and ages of children. According to Eren [30]'s study, teachers were also found to have a positive attitude towards portfolio assessment practices.

The following suggestions can be made according to the results of the research. In early childhood education, the teachers should be supported to use their alternative assessment approaches in a correct and effective manner. Besides, the level of knowledge of teachers on alternative assessment approaches should be increased with practices such as courses, seminars and workshops. Different methods and techniques for alternative assessment approaches can be explored. In-depth research on each approach can give more detailed information to the researcher in this regard.

\section{REFERENCES}

[1] Tunceli, H.İ. and R. Zembat, Erken çocukluk döneminde gelişimin değerlendirilmesi ve önemi. Journal of Education, Theory and Practical Research, 2017. 3(3): p. 1-12.

[2] Bredekamp, S., Erken çocukluk eğitiminde etkili uygulamalar, Ankara: Nobel, 2015.

[3] Özgüven, İ.E., Testler, Psikolojik. 6. Baskı ed. 2004, Ankara PDREM Publishing

[4] Shepard, L., S.L. Kagan, and E. Wurtz, Principles and Recommendations for Early Childhood Assessments. 1998.
[5] Karamustafaoğlu, S., A. Çağlak, and B. Meşeci, Alternatif Ölçme Değerlendirme Araçlarina İlişsin Sinif Öğretmenlerinin Öz Yeterlilikleri. Amasya Education Journal, 2012. 1(2): p. 167-179.

[6] Gullo, D.F., Understanding assessment and evaluation in early childhood education. Early Childhood Education Series. 2005, Columbia University: Teachers College Press.

[7] McLachlan, C., M. Fleer, and S. Edwards, Early childhood curriculum: Planning, assessment and implementation. 2010, New York: Cambridge University Press.

[8] Erdoğan, N.I. and M. Canbeldek, Erken Çocukluk Eğitiminde Ölçme ve Değerlendirme. Abant İzzet Baysal University, Journal of Education Faculty, 2017. 17 (3): p. 1306-1327.

[9] Bracken, B.A., The psychoeducational assessment of preschool children. 2004: Lawrence Erlbaum Associates.

[10] Lidz, C.S., Early childhood assessment. 2003, Canada: John Wiley \& Sons.

[11] MEB, Çocukları Tanıma/Değerlendirme. 2015, Ankara.

[12] Cotrus, A. and C. Stanciu, A study on dynamic assessment techniques, as a method of obtaining a high level of learning potential, untapped by conventional assessment. Procedia-Social and Behavioral Sciences, 2014. 116: p. 2616-2619.

[13] Bodrova, E. and D.J. Leong, Tools of the mind: The Vygotskian Approach to Early Childhood Education. 2007, Columbus, Ohio: Pearson.

[14] Demirtaş, Z., Eğitimde Program Değerlendirme Yaklaşımlarına Genel Bir Bakış. Sakarya University Journal of Education, 2017. 7(4): p. 756-768.

[15] Paulson, F.L., P.R. Paulson, and C.A. Meyer, What makes a portfolio a portfolio. Educational leadership, 1991. 48(5).

[16] Wright, L. and J.H. Borland, Using early childhood developmental portfolios in the identification and education of young, economically disadvantaged, potentially gifted students. Roeper Review, 1993. 15(4): p. 205-210

[17] Gibson, T.S., Student Evaluation in an Integrated Preschool Classroom. 1994.

[18] Karadağ, E. and A. Öney, İlköğretim Birinci Kademede Portfolyo Dosyalarının Değerlendirme Aracı Olarak Kullanılabilirliği. Ahi Evran University, Journal of Education Faculty, 2006. 7(2).

[19] Birgin, O., Alternatif değerlendirme yöntemi olarak portfolyo değerlendirme uygulamalarına ilişkin öğrenci görüşleri The Journal of Turkish Educational sciences, 2008. 6(1): p. 1-24

[20] Kuran, K. and F. Kanatlı, Alternatif Ölçme Değerlendirme Teknikleri Konusunda Sınıf Öğretmenlerinin Görüşlerinin Değerlendirilmesi/The Evaluation of Classroom Teachers' Opinions on the Alternative Assessments Techniques. Mustafa Kemal University, The Journal of Institute of Social Sciences, 2009. 6(12).

[21] Demirören, M., et al., Bir öğrenme ve değerlendirme yöntemi olarak "Portfolyo". Journal of Ankara University Faculty of Medicine, 2014. 62(01): p. 19-24. 
[22] Topuz, G.Y. and Ö.M.E. Kaya, Okulöncesi Eğitim Öğretmenlerinin Çocukları Tanıma ve Değerlendirme Amaçlı Yapılan Çalışmalara İlişkin Görüşleri. Anadolu Journal of Educational Sciences İnternational, 2017. 6(1).

[23] Buldu, M. and F.T. Erden, An Investigation of Turkish Early Childhood Teachers' Self-Reported Beliefs and Practices Regarding Assessment. Journal of Education, 2017(11): p. 29-49.

[24] Buyukozturk, S., et al., Bilimsel arastirma yontemleri. Ankara: Pegem Akademi Publishing Vol. (13th Ed.) 2012.

[25] Türnüklü, A., Eğitimbilim araștırmalarında etkin olarak kullanılabilecek nitel biraraştırma tekniği: Görüşme. Educational Administration: Theory and Practise 2000. 6(4): p. 543-559.

[26] Yıldırım, A. and H. Şimşek, Nitel araştırma yöntemleri. Ankara: Seçkin Publishing. (2nd Ed.) 2000

[27] Çoruhlu, T.Ş., S.E. Nas, and S. Çepni, Fen ve teknoloji öğretmenlerinin alternatif ölçme-değerlendirme tekniklerini kullanmada karşılaştıkları problemler: Trabzon örneği. Yüzüncü Y1l University, Journal of Education Faculty, 2014. 6(1): p. 122-141.

[28] Sezer, Ç., Okul Öncesi Öğretmenlerinin Ölçme Değerlendirmeyi Kullanma Düzeylerinin Belirlenmesi. (Unpublished Thesis) 2010, Çanakkale Onsekiz Mart Üniversity, Social Sciences Institute, Preschool Teacher Çanakkale.

[29] Özkan, F., Okul Öncesi Eğitimde Değerlendirme Sürecine Yöenlik Aile-Öğretmen Görüş ve Beklentilerinin İncelenmesi. (Unpublished Thesis) 2015, Hacettepe University, Institute of Education Sciences Preschool Education Program: Ankara.

[30] Eren, T., Ev ve Okul Arasındaki Köprü: Okul Öncesi Eğitimde Portfolyo. 2007, Middle East Technical University, Institute of Education Sciences, Early Childhood Education: Ankara.

i This study has been presented as an oral representation paper Globets 2018 (An International Conference Education, Technology and Science) in Serbia, 6-9 May, 2018. 